\title{
Hepatitis B virus (HBV)-specific T-cell responses to recombinant HBV core protein in patients with normal liver function and co-infected with chronic HBV and human immunodeficiency virus 1 (HIV-1)
}

Xin Zhang ${ }^{1 \dagger}$, Hanqian Xing ${ }^{2 \dagger}$, Xia Feng $^{1}$, Haiping Zhang ${ }^{1}$, Yi Wang ${ }^{1}$ and Huiping Yan ${ }^{1 *}$

\begin{abstract}
Background: Little is known about HBV-specific T-cell responses in chronic Hepatitis B patients (HBV) that are coinfected with Human immunodeficiency virus type 1 (HIV-1), especially those with normal alanine aminotransferase (ALT) levels.

Methods: Twenty-five patients with chronic HBV (11 hepatitis B e antigen [HBeAg]-positive, 14 HBeAg-negative) were enrolled in a cross-sectional study. A longitudinal study as also conducted in which follow-up was done at 3 , 12, and 24 months, after acute HIV-1 infection, in 11 individuals who also had chronic HBV. Peripheral blood mononuclear cells were stimulated with recombinant HBV surface protein (S protein), core protein (C protein) or gag peptide. IFN- $\gamma$-secreting T cells were identified by ELISPOT assay.

Results: In the cross-sectional study, co-infected chronic HBV patients had lower C protein-specific T-cell responses compared with mono-infected individuals, though the difference was not significant. In co-infected, chronic HBV patients, the magnitude of $\mathrm{C}$ protein-specific T-cell responses was significantly greater in HBeAg-positive subjects compared to HBeAg-negative subjects $(p=0.011)$. C protein-specific T-cell responses were positively correlated with HBV viral load $\left(r_{s}=0.40, p=0.046\right)$. However, gag-specific T-cell responses were negatively correlated with HIV viral load $\left(r_{s}=-0.44, p=0.026\right)$ and positively correlated with $C D 4^{+}$count $\left(r_{s}=0.46, p=0.021\right)$. The results were different in mono-infected individuals. PBMCs from co-infected HBeAg-positive patients secreted more specific-IFN- $\gamma$ in cultured supernatants compared with PBMCs from co-infected HBeAg-negative patients $(p=0.019)$. In the longitudinal study, S protein- and C protein-specific T-cell responses were decreased as the length of follow-up increased ( $p=0.034$, for S protein; $p=0.105$, for C protein). Additionally, the S protein- and C protein-specific T-cell responses were significantly higher in $\mathrm{HBeAg}$-positive patients than in $\mathrm{HBeAg}$-negative patients at 3 and 12 months after HIV-1 infection (all $p<0.05$ ), but not at 24 months. A positive correlation (trend) was found between $\mathrm{C}$ protein-specific T-cell responses and HBV viral load at 3 and 12 months after HIV-1 infection.

Conclusions: HBV-specific T-cell responses to recombinant HBV core protein were reduced in chronic HBV patients co-infected with HIV-1. The reduced C protein-specific T cell responses were positively correlated with HBV viral load in co-infected, chronic HBV patients.
\end{abstract}

\footnotetext{
*Correspondence: yhp503@126.com

${ }^{\dagger}$ Equal contributors

'Infection and Immunity Research center of Beijing Youan Hospital, Capital

Medical University, Beijing, China100069

Full list of author information is available at the end of the article
} 


\section{Background}

Patients with Human immunodeficiency virus type 1 $(\mathrm{HIV}-1)$ are frequently found to be co-infected with Hepatitis B virus (HBV). These patients often have a high prevalence of hepatitis B surface antigen (HBsAg)or hepatitis B core antibody (HBcAb)-positive HBV serological markers due to common infection routes. Worldwide, it is estimated that $70-90 \%$ of $\mathrm{HIV}-1$ patients have evidence of previous HBV infection and 5$15 \%$ of $\mathrm{HIV}-1$ patients have current $\mathrm{HBV}$ infection and are $\mathrm{HBsAg}$ positive. $\mathrm{HBV}$ individuals that are coinfected with HIV seroconvert from hepatitis B precore antigen (HBeAg) to anti-HBeAg antibody (HBeAb) less frequently, have higher HBV DNA levels, lower levels of alanine aminotransferase (ALT) and a history of milder necroinflammatory activity, compared to those infected with HBV only [1-4]. In the presence of HIV-1, the progression of HBV related liver disease is accelerated and liver related mortality is significantly increased $[5,6]$. Additionally, there is an increased risk of persistent chronic infection in individuals infected with HIV-1 who are subsequently infected with HBV [7]. Previous studies have also shown a relatively high prevalence of occult Hepatitis B in HIV-1-infected patients, especially after the withdrawal of antiretroviral therapy. Therefore, determining the pathogenesis associated with HIV-1 and HBV interaction, including the modification of the immune responses, will allow for the development of a rational approach for the management of coinfected individuals.

In persistent $\mathrm{HBV}$ monoinfection, there is a reduction in $\mathrm{HBV}$-specific $\mathrm{CD}_{4}^{+}$and $\mathrm{CD}^{+} \mathrm{T}$ cells compared with individuals that have successfully cleared the infection. It has been suggested that $\mathrm{HBeAg}$ plays a role in facilitating $\mathrm{HBV}$ persistence by depleting $\mathrm{HBeAg-}$ and HBcAg-specific Th1 CD4 ${ }^{+} \mathrm{T}$ cells [8]. The reduction in antigen burden following anti-HBV treatment may reduce $\mathrm{T}$ cell tolerance and exhaustion, allowing for a more efficient HBV-specific T-cell and B-cell immune response against either $\mathrm{HBeAg}$ and/or $\mathrm{HBsAg}$ [9]. Many previous studies have focused on the alteration of immune responses in HIV/HBV patients with abnormal liver function and lower CD4 counts, however little is known about individuals with milder liver disease that have normal levels of ALT and higher CD4 counts. In the present study, we examined whether HBV-specific T-cell responses in chronic HBV patients could be influenced by the presence or absence of HBeAg or by the level of HBV DNA, in the presence of HIV-1. Recombinant $\mathrm{S}$ and $\mathrm{C}$ proteins were used as a stimulus, in both cross-sectional and longitudinal studies, to assess changes in the HBVspecific total T-cell responses in chronic HBV patients with HIV-1 co-infection.

\section{Results}

Patient characteristics

In cross-sectional study, demographic and clinical details of 25 co-infected chronic HBV patients and 16 monoinfected chronic HBV patients are summarized in Table 1. All co-infected chronic HBV patients had normal liver function, as determined by ALT, AST, and TBIL analysis, within two years of observation. The HIV/HBV co-infected patients mainly included high-risk men-who-have-sexwith-men (MSM). The HBV viral load in the co-infected, chronic HBV patients was comparable to that of the mono-infected, chronic HBV patients. HBV viral load was not correlated with HIV viral load in co-infected, chronic HBV cases. Demographic and clinical details of patients with previous $\mathrm{HBV}$ infection, who were co-infected with HIV $(\mathrm{n}=14)$ and who were not co-infected with HIV $(\mathrm{n}=16)$, are summarized in Table 2 . HIV patients that had previous HBV infection mainly included high-risk MSM, and had normal liver function, as determined by ALT, AST, TBIL analysis, within two years of observation. The HBV viral load in co-infected patients that had been previously infected with HBV was comparable to that of mono-infected patients that had been previously infected with HBV.

In the longitudinal study, 11 individuals with acute HIV-1 and chronic HBV infection had normal levels of ALT, AST and TBIL during the 2-year follow-up (Subject demographic and clinical details are summarized in Table 3).

In the cross-sectional study, HBV-specific T-cell responses in co-infected individuals were decreased compared to mono-infected individuals

There was no significant difference in the response frequency to $\mathrm{C}$ protein when comparing co-infected, chronic HBV patients and mono-infected, chronic HBV patients (22/25 and 15/16 responded to C-protein, respectively). The magnitude of the $\mathrm{C}$ protein induced HBV-specific $\mathrm{T}$ cell responses in co-infected, chronic HBV patients was lower than in mono-infected, chronic HBV patients, however the difference was not statistically significant $(\mathrm{p}>$ 0.05; Figure 1 left). On the other hand, in co-infected, chronic HBV patients, gag-specific $\mathrm{T}$ cell responses were the highest with all 3 stimuli, including $S$ protein, $C$ protein and gag peptide $(\mathrm{p}=0.0004)$. Gag-specific $\mathrm{T}$ cell responses were also higher than $\mathrm{S}$ protein- and $\mathrm{C}$ proteinspecific $\mathrm{T}$ cell responses (all $\mathrm{p}<0.05$; Figure 1 left). In mono-infected, chronic HBV patients, the magnitude of $\mathrm{C}$ protein-specific $T$ cell responses was greater than that of $S$ protein-specific $\mathrm{T}$ cell responses ( $\mathrm{p}<0.0001$; Figure 1 left).

The response to $C$ protein was less frequent in HIV patients that had previous HBV infection, compared to patients that had previous $\mathrm{HBV}$ infection but who did not have HIV (9/14 and 15/16 responded to C protein, 
Table 1 Demographics of chronic HBV patients

\begin{tabular}{|c|c|c|c|c|c|c|}
\hline \multirow[t]{2}{*}{ Parameter } & \multicolumn{3}{|c|}{ Single HBV infection } & \multicolumn{3}{|c|}{ HIV/HBV coinfection } \\
\hline & $\mathrm{HBeAg}^{+}$ & $\mathrm{HBeAg}^{-}$ & $P$ value & $\mathrm{HBeAg}^{+}$ & $\mathrm{HBeAg}^{-}$ & $P$ value \\
\hline No. of Subjects & 8 & 8 & & 11 & 14 & \\
\hline Gender(no. male/female) & $7 / 1$ & $6 / 2$ & $N S^{a}$ & $11 / 0$ & $13 / 1$ & $N S^{a}$ \\
\hline Age [median (range)] (yr) & $36(22-60)$ & $38(25-67)$ & $N S^{b}$ & $34(23-40)$ & $32(25-56)$ & $N S^{b}$ \\
\hline ALT [median (range)] (U/L) & $19.2(6.1-53)^{c}$ & $23.7(12.2-40)$ & $N S^{b}$ & $22.4(13.5-58)^{c}$ & $19.2(13.7-38)$ & $N S^{b}$ \\
\hline HBV DNA ${ }^{d}$ [median (range)] & $7.71(0-9.04)$ & $1.04(0-4.32)$ & $<0.01$ & $6.85(0-8.51)$ & $1.35(0-8.98)$ & $<0.01$ \\
\hline HIV RNA ${ }^{\mathrm{d}}$ [median (range)] & NA & NA & & $4.8(0-5.4)$ & $4.98(0-5.9)$ & $N S^{b}$ \\
\hline CD4 count [median (range)] (cells/ul) & NA & NA & & $452(211-862)$ & $332(122-704)$ & $N S^{b}$ \\
\hline
\end{tabular}

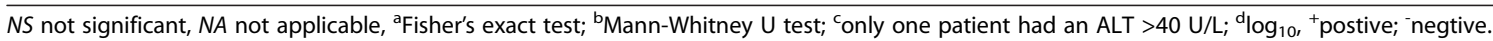

respectively; $\mathrm{p}=0.072$ ). The magnitude of $\mathrm{C}$ proteinspecific T-cell responses was significantly weaker in individuals that had been previously infected with HBV and who were co-infected with HIV compared to those who were not co-infected with $\operatorname{HIV}(\mathrm{p}=0.003$; Figure 1 right), however there was no significant difference between these groups in specific T-cell responses to $\mathrm{S}$ protein. The median number of total $\mathrm{T}$ cells was comparable in co-infected and mono-infected individuals that had previous HBV infection (1346[539-3463]/uL vs. 1361[689-2116]/uL, respectively). Similarly, the total $\mathrm{T}$ cell percentage was not significantly different between these two groups. The fact that total $\mathrm{T}$ cell number and percentage were not decreased, and that $C$ proteinspecific $\mathrm{T}$ cell responses were decreased, implies that $\mathrm{HBV}$-specific $\mathrm{T}$ cell responses may be impaired in the presence of HIV-1 infection.

Table 2 Demographics of individuals previously infected with HBV

\begin{tabular}{|c|c|c|c|}
\hline Parameter & $\begin{array}{l}\text { Without HIV } \\
\text { coinfection }\end{array}$ & $\begin{array}{l}\text { With HIV } \\
\text { coinfection }\end{array}$ & $P$ value \\
\hline No. of patients & 16 & 14 & \\
\hline Gender (no. male/female) & $9 / 7$ & $13 / 1$ & $0.039^{a}$ \\
\hline \multicolumn{4}{|l|}{ Age } \\
\hline [median(range)] (yr) & $31(23-46)$ & $33(23-54)$ & $N S^{b}$ \\
\hline \multicolumn{4}{|l|}{ ALT } \\
\hline [median(range)] (U/L) & $13(4-30)$ & $15.5(3-50)^{c}$ & $N S^{b}$ \\
\hline \multicolumn{4}{|l|}{ HBV DNA ${ }^{d}$} \\
\hline [median(range)] & $<500$ & $<500$ & $N S^{b}$ \\
\hline \multicolumn{4}{|l|}{ HIV RNA $^{d}$} \\
\hline [median(range)] & NA & $4.45(0-4.93)$ & NA \\
\hline \multicolumn{4}{|l|}{ CD4 T cell count } \\
\hline [median(range)] (cells/ul) & NA & $323(76-640)$ & NA \\
\hline
\end{tabular}

NS not significant, NA not applicable, ${ }^{\mathrm{a}}$ Fisher's exact test; ${ }^{\mathrm{b}}$ Mann-Whitney $\mathrm{U}$

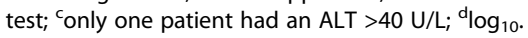

HBV viral load was correlated with the magnitude of HBV-specific T-cell responses in chronic HBV patients co-infected with HIV

To analyze whether HBV viral load could affect the magnitude of HBV-specific T-cell responses in co-infected, chronic HBV patients, 25 subjects were divided into two groups according to the lower limit of the HBV viral load (lower detection limit of 500 copies $/ \mathrm{mL}$ ). As shown in Figure $2 \mathrm{~B}$, the magnitude of $\mathrm{C}$ protein-specific $\mathrm{T}$-cell responses was significantly greater in subjects with an HBV viral load $>500$ copies $/ \mathrm{mL}$ compared to subjects with an HBV viral load $<500$ copies $/ \mathrm{mL}(\mathrm{p}=0.023)$. This difference was not observed in chronic HBV patients without HIV coinfection.

The relationship between $\mathrm{HBV}$ viral load and the magnitude of $\mathrm{HBV}$-specific $\mathrm{T}$-cell responses was also analyzed in the 25 co-infected, chronic HBV patients. As shown in Figure 2A, the $\mathrm{C}$ protein-specific $\mathrm{T}$-cell responses were significantly positively correlated with $\mathrm{HBV}$ viral load $\left(\mathrm{r}_{\mathrm{s}}=0.40, \mathrm{p}=0.046\right)$. However, the magnitude of the HBV-specific T-cell response was not correlated with $\mathrm{CD} 4^{+} \mathrm{T}$ cell count or HIV viral load. The magnitude of gag-specific $\mathrm{T}$-cell response was positively correlated with $\mathrm{CD}^{+}{ }^{+} \mathrm{T}$ cell count $\left(\mathrm{r}_{\mathrm{s}}=0.46, \mathrm{p}=0.021\right.$; Figure $2 \mathrm{C}$ ), but negatively correlated with HIV viral load $\left(r_{s}=-0.44, p=0.026\right.$; Figure 2D). Gag-specific $\mathrm{T}$ cell responses were significantly lower in co-infected, chronic HBV patients with an HIV viral load $>5\left(\log _{10}\right)$ than in co-infected, chronic HBV patients with an HIV viral load $<5\left(\log _{10}\right)(\mathrm{p}=0.005)$, though the difference in $\mathrm{HBV}$-specific T-cell response was insignificant between these two groups. These data indicate that HBV-specific $\mathrm{T}$-cell responses are higher in patients with higher HBV viral loads, but gag-specific $\mathrm{T}$-cell responses are weaker in patients with lower $\mathrm{CD}^{+}$counts and higher HIV viral loads.

However, HBV-specific T-cell responses were not related to $\mathrm{HBV}$ viral load in mono-infected, chronic HBV patients. 
Table 3 Demographics of individuals with chronic HBV and acute HIV-1 co-infection

\begin{tabular}{|c|c|c|c|c|c|c|c|c|c|c|}
\hline \multirow[b]{2}{*}{ Patient } & \multirow[b]{2}{*}{ HBeAg } & \multicolumn{3}{|c|}{ v1 } & \multicolumn{3}{|c|}{ v2 } & \multicolumn{3}{|c|}{ v3 } \\
\hline & & $\mathrm{HBV} \mathrm{DNA}^{\mathrm{a}}$ & HIV RNA $^{a}$ & CD4 count & $\mathrm{HBV} \mathrm{DNA}^{\mathrm{a}}$ & HIV RNA $^{a}$ & CD4 count & HBV DNA ${ }^{a}$ & HIV RNA $^{a}$ & CD4 count \\
\hline $\mathrm{AHI01}$ & pos & 8.45 & 5.66 & 376 & 7.38 & 5.66 & 212 & $3.52^{b}$ & $<|d|^{b}$ & 376 \\
\hline $\mathrm{AHIO2}$ & pos & 6.54 & 4.55 & 533 & 7.43 & 4 & 298 & 7.76 & ND & 405 \\
\hline $\mathrm{AHI03}$ & neg & $<|d|$ & 3.89 & 213 & $<|d|$ & ND & 192 & $<|d|$ & ND & 189 \\
\hline $\mathrm{AHI04}$ & pos & 7.71 & 3.75 & 345 & 8.2 & 4.47 & 275 & 8.4 & ND & 342 \\
\hline $\mathrm{AHI05}$ & pos & 9.04 & 5.72 & 363 & 8.32 & ND & 292 & 7.14 & ND & 363 \\
\hline AHI06 & neg & $<|d|$ & 2.23 & 361 & $<|d|$ & ND & 345 & $<|d|$ & ND & 221 \\
\hline $\mathrm{AHI07}$ & pos & 8.14 & 6.1 & 412 & 8.45 & ND & 329 & 7.54 & ND & 293 \\
\hline $\mathrm{AHI08}$ & neg & $<|d|$ & 4.92 & 308 & $<|d|$ & 4.67 & 365 & $<|d|$ & ND & 395 \\
\hline AHI09 & neg & $<|d|$ & 3.39 & 922 & $<|d|$ & 3.3 & 862 & $<|d|$ & ND & 692 \\
\hline AHI10 & neg & $<|d|$ & 6.31 & 380 & $<|d|$ & ND & 464 & $<|d|$ & ND & 243 \\
\hline AHI11 & neg & $<|d|$ & 5.62 & 221 & $<|\mathrm{d}|$ & ND & 445 & $<|d|$ & ND & 445 \\
\hline
\end{tabular}

pos HBeAg positive, neg HBeAg negative; v1, 2, 3: followed up on $3^{\text {rd }}, 12^{\text {th }}, 24^{\text {th }}$ month post acute HIV-1 infection; ${ }^{\text {a }} \log _{10}$; ${ }^{\text {b } H A A R T ~ w i t h ~ A Z T / 3 T C / L P V r ; ~ I d l ~ l o w e r ~}$ limit of detection, $N D$ not done.

\section{Relationship of HBV-specific T-cell responses to the presence of $\mathrm{HBeAg}$}

HBV-specific T-cell responses to the presence of $\mathrm{HBeAg}$ were examined in co-infected, chronic HBV patients since HBeAg is an immunotoleragen [8]. Subjects were divided into $\mathrm{HBeAg}$ negative and $\mathrm{HBeAg}$ positive groups. The magnitude of the $\mathrm{C}$ protein-specific $\mathrm{T}$-cell response was no different in HBeAg-positive, mono-infected, chronic HBV patients than in HBeAg-negative, mono-infected, chronic HBV patients ( $p>0.05$; Figure $3 \mathrm{~A}$ right). In contrast, the magnitude of the $\mathrm{C}$ protein-specific $\mathrm{T}$-cell response was significantly greater in HBeAg-positive, co-infected, chronic $\mathrm{HBV}$ patients than in HBeAg-negative, co-infected, chronic HBV patients ( $\mathrm{p}=0.011$; Figure 3A left).
Cytokine responses in cultured supernatants of PBMCs from co-infected, chronic HBV patients

To further ascertain whether HBeAg-positive, co-infected, chronic HBV patients have higher cytokine productivity compared to $\mathrm{HBeAg-negative,} \mathrm{co-infected,} \mathrm{chronic} \mathrm{pa-}$ tients, the levels of IL-2, IL-4, IL-6, IL-8, IL-10, GM-CSF, TNF- $\alpha$, and IFN- $\gamma$ secreted by PBMCs, stimulated with recombinant $C$ protein, were measured in cultured supernatant. The level of IFN- $\gamma$ secreted by HBeAg-positive patients was significantly higher than that secreted by HBeAg-negative patients $(92.09[0.02 \sim 186.21] \mathrm{pg} / \mathrm{mL}$ vs. $28.33[0.02 \sim 80.22] \mathrm{pg} / \mathrm{mL}$, respectively; $\mathrm{p}=0.031$ ). Moreover, the stimulation in index for cytokine IFN- $\gamma$ was significantly higher for HBeAg-positive patients than for

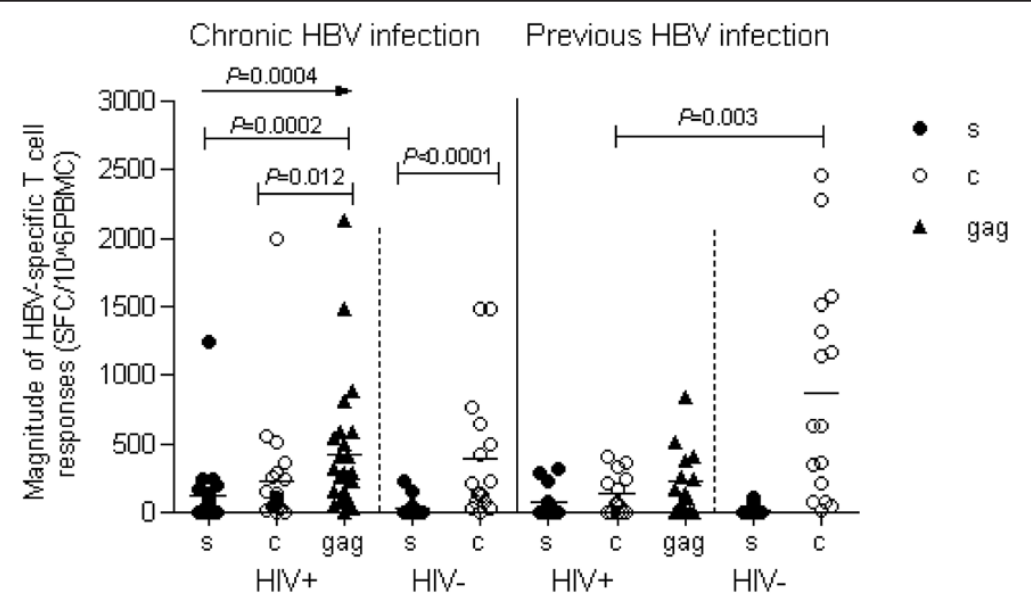

Figure 1 Magnitude of HBV-specific T-cell responses induced in HBV patients with and without HIV infection. Left, chronic HBV infection; right, previous HBV infection, HIV+, co-infected with HIV; HIV-, not co-infected with HIV. s: stimulated by S protein; c: stimulated by C protein; gag: stimulated by gag peptide pool. 

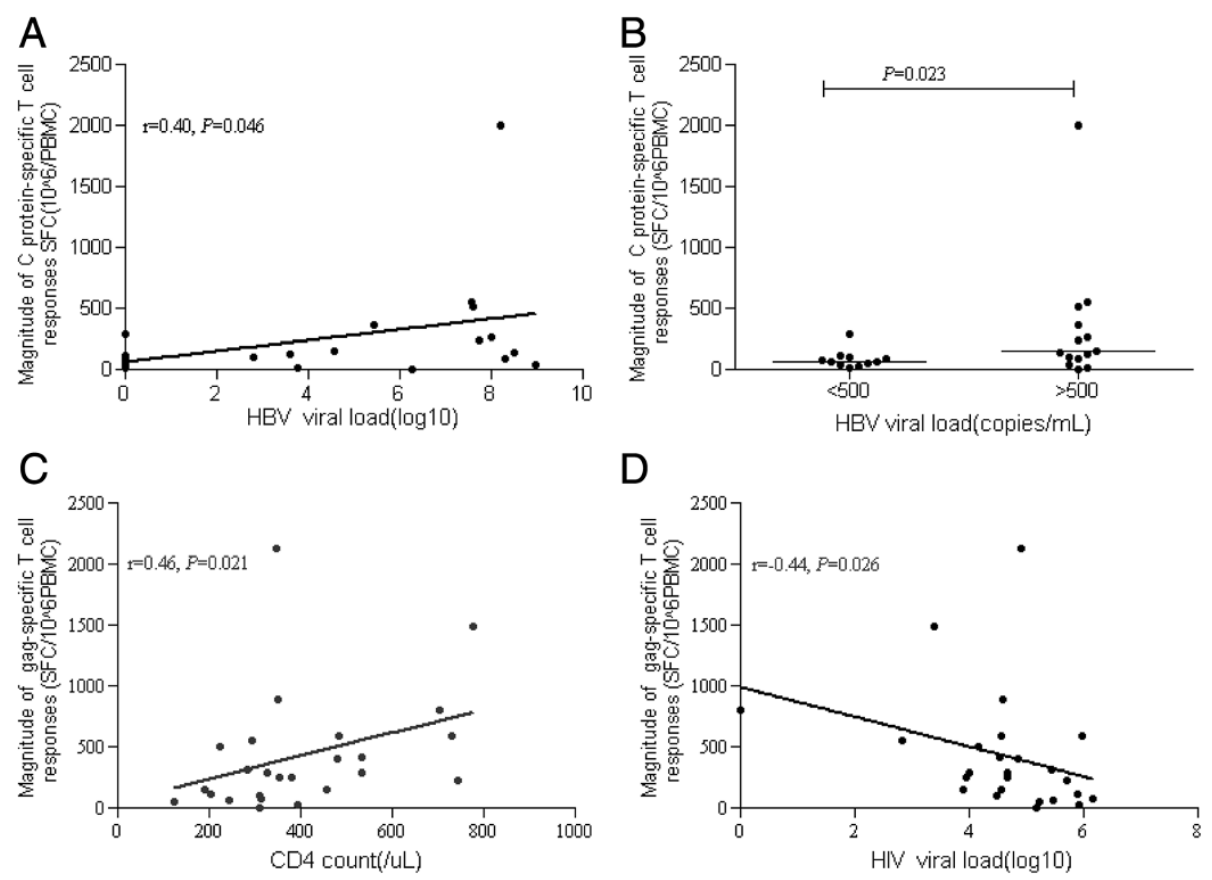

Figure 2 Correlation of various HBV and HIV associated variables. (A) Correlation of HBV viral load and HBV-specific T-cell responses elicited by chronic HBV patients co-infected with HIV. (B) Comparison of HBV-specific T-cell responses induced by HBV-infected patients with HIV coinfection grouped by HBV viral load ( $<500$ copies $/ \mathrm{mL}$ or $>500$ copies $/ \mathrm{mL}$ ). The relation of CD4 count (C) and HIV viral load (D) on gag-specific T-cell responses elicited by chronic HBV patients co-infected with HIV.

HBeAg-negative patients ( $\mathrm{p}=0.019$; Figure $3 \mathrm{~B})$. However, there were no significant differences in stimulation indices for IL-2, IL-4, IL-6, IL-8, IL-10, GM-CSF, or TNF- $\alpha$ among the two subgroups.

In the longitudinal study, HBV-specific T-cell responses were lower in patients with chronic HBV infection with disease progression

The magnitude of HBV-specific T-cell responses was analyzed in 11 subjects that had been diagnosed as having acute HIV-1 infection and chronic HBV infection concurrently. As shown in Figure 4, S protein- and C proteinspecific T-cell responses decreased as the length of followup increased $(p=0.034$, for $S$ protein; $p=0.105$, for $C$ protein; Figure 4A). S protein- and $C$ protein-specific Tcell responses were significantly higher at 3 months after $\mathrm{HIV}$ infection than at 24 months after HIV infection (all $\mathrm{p}<0.05$; Figure $4 \mathrm{~A}$ ). Furthermore, the magnitude of $\mathrm{C}$ protein-specific $\mathrm{T}$-cell responses was positively correlated with the levels of HBV DNA at 3 and 12 months post-
A

C protein-specific T cell responses

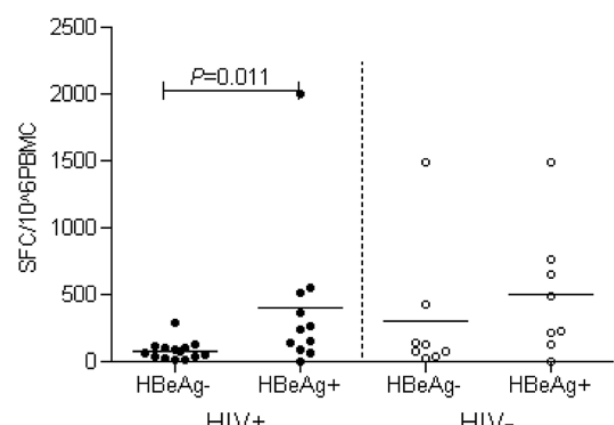

B

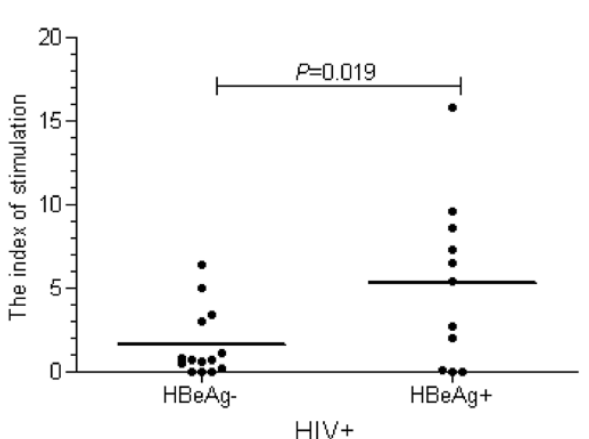

Figure 3 Comparison of HBV-specific cell responses in the presence or absence of HBeAg. (A) C protein-specific T-cell responses elicited in ELISPOT assay; (B) Cytokine IFN-Y responses in cultured supernatants of PBMCs stimulated by C protein. HBeAg(-): HBeAg-negative subjects; HBeAg(+): HBeAg-positive subjects; HIV+: HIV co-infected; HIV-: not co-infected with HIV. 

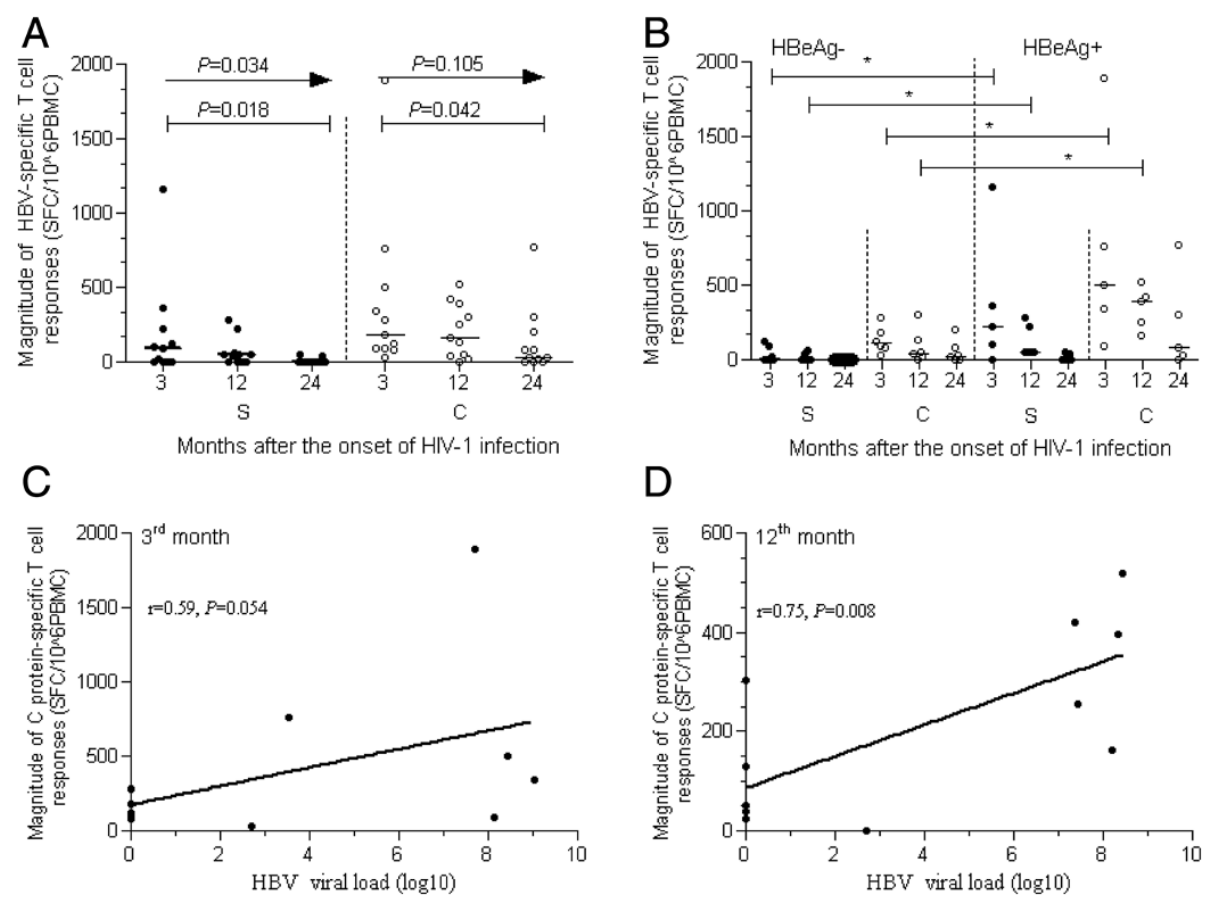

Figure $4 \mathrm{HBV}$-specific T-cell responses induced in co-infected, chronic HBV patients followed up 3, 12, and 24 months after the onset of acute HIV-1 infection. (A) the difference of HBV-specific T-cell responses elicited at different time points; (B) comparison of HBV-specific T-cell responses in the presence or absence of HBeAg; (C) correlation between C protein-specific T-cell responses and HBV viral load 3 months after the onset of acute HIV-1 infection; (D) correlation between C protein-specific T-cell responses and HBV viral load 12 months after the onset of acute HIV-1 infection; ${ }^{*} \mathrm{P}<0.05$ (Figure 4B); HBeAg: HBeAg negative; $\mathrm{HBeAg}^{+}$: HBeAg positive.

HIV infection $\left(r_{s}=0.59, p=0.054\right.$; Figure $4 \mathrm{C}$ and $r_{s}=0.75$, $\mathrm{p}=0.008$; Figure 4D; respectively). Given the effects of $\mathrm{HBeAg}$ as an immunotoleragen, the relationship of the presence or absence of HBeAg to the HBV-specific T-cell response was also investigated. We found that the magnitude of $\mathrm{S}$ and $\mathrm{C}$ protein-specific $\mathrm{T}$-cell responses in HBeAg-positive individuals was significantly higher than in HBeAg-negative patients at 3 and 12 months after HIV infection (all $\mathrm{p}<0.05$; Figure 4B), however there was no difference between HBeAg-positive and -negative patients at 24 months after HIV infection.

\section{HBV-specific T-cell responses, stimulated by $\mathrm{S}$ and $\mathrm{C}$ proteins, are mediated by $\mathrm{CD}^{+}$and $\mathrm{CD}^{+} \mathrm{T}$ cells}

To identify the specific T-cell responses induced by a stimulus, $\mathrm{CD} 4^{+}$and $\mathrm{CD}^{+}$cells were isolated from PBMCs and an ELISPOT assay was performed. CD4 $4^{+} \mathrm{T}$ cells induced approximately $70-80 \%$ of the HBV-specific T-cell responses and $\mathrm{CD}^{+}$cells induced approximately $20-30 \%$ of the HBV-specific T-cell responses. In contrast, $\mathrm{CD}^{+}$cells induced about $96 \%$ of the gag-specific T-cell responses, but $\mathrm{CD}^{+}$cells induced very little of the gagspecific T-cell responses.

\section{Discussion}

In the cross-sectional study, HBV-specific T-cell responses in chronic HBV patients, co-infected with HIV, were described. Specific T-cell responses, induced by $\mathrm{S}$ protein, were lower than specific T-cell responses induced by $\mathrm{C}$ protein regardless of whether the subject had an HIV coinfection. This is consistent with the previous studies that showed that chronic HBV infection is generally associated with a narrow HBV-specific response, with the dominant responses often directing the core protein $[10,11]$. Overall, in the co-infected, chronic HBV patients, HBV-specific T-cell responses were weaker than in the mono-infected patients, though the difference was not significant. Mono-infected, chronic HBV patients had significantly weaker $C$ protein-specific $\mathrm{T}$-cell responses compared to those without HIV who were previously infected with HBV ( $p=0.021$, data not shown). However, the magnitude of $\mathrm{C}$ protein-specific $\mathrm{T}$-cell response was comparable in co-infected, chronic HBV patients and individuals that had HIV who were previously infected with HBV ( $p>0.05$, Figure 1). HBeAg has been described as an immunologic toleragen, however it is not clear whether HBeAg has suppressive effects on the immune response to HBV in the presence of HIV-1. We found no significant 
difference in $\mathrm{C}$ protein-specific $\mathrm{T}$-cell responses between HBeAg-positive patients with HIV-1 and HBeAg-positive patients without HIV-1. However, co-infected, HBeAgpositive patients had greater HBV-specific T-cell responses than co-infected, HBeAg-negative patients. Furthermore, there was no relationship between $C$ protein-specific $T$ cell responses and the level of HIV RNA or CD4 count in co-infected, HBeAg-positive patients (data not shown). Based on these observations, it appears that HBeAg does not have suppressive effects on HBV-specific T-cell responses in the presence of HIV-1.

The magnitude of $\mathrm{HBV}$-specific T-cell responses was positively correlated with the level of HBV DNA in coinfected, chronic HBV patients. However, this was not the case in mono-infected, chronic HBV patients. Similar results were observed were in the longitudinal study. Therefore, we hypothesize that the greater $\mathrm{HBV}$-specific $\mathrm{T}$-cell responses seen in chronic $\mathrm{HBV}$ patients with HIV-1 may be related to higher levels of HBV DNA. This observation is contradictory to previous studies that indicating that a reduction in HBV viral load may lead to a loss of HBV anergy in chronic HBV patients [12,13]. One possible explanation for this discrepancy is that the anergy to HBV seen in our study may have been partly activated by HIV-1 co-infection. An alternative explanation is that HBV-specific $\mathrm{T}$ cells may migrate from the liver to the periphery in the presence of HIV-1, as observed with antiviral HBV therapy [14], however the precise reason(s) and mechanism(s) need to be explored.

We found that HBeAg-positive patients with higher levels of plasma HBV viral load, had greater HBV-specific T-cell responses than $\mathrm{HBeAg-negative} \mathrm{patients} \mathrm{with} \mathrm{no} \mathrm{or} \mathrm{very}$ low levels of HBV viral load. Conversely, in mono-infected, chronic HBV patients, there was no difference in HBVspecific T-cell responses between HBeAg-positive and negative patients (Figure 3), despite significant differences in HBV DNA levels. This finding was further confirmed by data showing that cultured supernatants from $\mathrm{HBeAg}-$ positive patients contained more specific-IFN- $\gamma$ than that from $\mathrm{HBeAg-negative} \mathrm{patients,} \mathrm{although} \mathrm{there} \mathrm{was} \mathrm{no} \mathrm{dif-}$ ference in levels of IL-2, IL-4, IL-6, IL-8, IL-10, GM-CSF, or TNF- $\alpha$ between HBeAg-positive and -negative patients. Additionally, we found that $\mathrm{HBeAg}$-positive individuals had stronger HBV-specific T-cell responses than HBeAgnegative patients at 3 and 12 months after the onset of acute HIV-1 infection. These findings are contradictory to the Chang et al. study which reported that the magnitude of the HBV-specific IFN- $\gamma$-positive $\mathrm{CD}^{+}{ }^{+} \mathrm{T}$-cell response was not significantly different between $\mathrm{HBeAg}$-positive and -negative patients in HIV/HBV co-infected, ART naïve patients [15]. The distinct immunogenicity of stimulus antigens used in the two studies may have led to the different outcomes. Chang et al. [15] used a 15 amino acid peptide pool of four proteins, however 14-22 amino acid peptides are typically used to induce either $\mathrm{CD}^{+}$or $\mathrm{CD}^{+} \mathrm{T}$-cell responses [16] and mainly induce a $\mathrm{CD}^{+} \mathrm{T}$-cell response [17]. Recombinant whole protein can be used to detect CD4-mediated responses and a limited CD8-mediated response $[16,18]$. In this study, HBV-specific T-cell responses were not only mediated by $\mathrm{CD} 4^{+} \mathrm{T}$-cells but also by $\mathrm{CD}^{+}$T-cells, as described by Kalyuzhny et al. [16], when recombinant protein was used as the stimulus. An alternative explanation is that the different disease statuses may have contributed to the different outcomes. Patients in the present study were considered to have mild disease, had normal ALT levels for at least two years and higher CD4 counts, however the patients in the Chang study had more severe disease with higher ALT levels and lower CD4 counts.

In chronic $\mathrm{HBV}$ infection, ALT is considered a marker of hepatic necrosis and inflammation. A lower ALT level reflects less hepatocyte destruction, which contributes to weak HBV-specific T-cell responses $[19,20]$. In the current study, the co-infected, chronic HBV patients had normal ALT levels during the two years of observation. One of possible explanation is that the HBV-specific Tcell responses were weak. In fact, $\mathrm{C}$ protein-specific $\mathrm{T}$ cell responses in co-infected, chronic HBV patients were much weaker than in individuals who had been previously infected HBV, but did not have HIV ( $p=0.005$, data not shown). Moreover, the impaired quality of HBV-specific $\mathrm{CD}^{+}$T-cells [15] and concurrent loss of $\mathrm{CD}^{+}$cells in coinfected, chronic HBV patients could result in $\mathrm{HBV}$ virus not being cleared, thus prolonging the chronic HBV infection. Nevertheless, the biological significance of these findings and their association with normal liver function and clinical progression remains to be determined.

Previous studies have reported that individuals recover from $\mathrm{HBV}$ infection by acquiring specific immunity to $\mathrm{HBV}$. In the current cross-sectional study, we also found that individuals who had been previously infected with HBV (without HIV co-infection) had stronger HBV specific T-cell responses. However, HBV-specific T-cell responses in individuals previously infected with $\mathrm{HBV}$ were exceptionally lower in the presence of HIV-1 (Figure 1); the precise reason(s) and/or mechanism(s) for this need to be analyzed. As observed in the crosssectional study, $\mathrm{CD}^{+}$cells mainly induced $\mathrm{C}$ proteinspecific T-cell responses. Chang et al. [21] reported that $\mathrm{HBV}$-specific $\mathrm{CD}^{+}{ }^{+} \mathrm{T}$ cells were reduced in $\mathrm{HIV} / \mathrm{HBV}$ co-infected, chronic patients that received HBV antiretroviral therapy. Thus, we believe that the loss of CD4 + $\mathrm{T}$ cells could lead to a significantly decreased CD4specific immune response to $\mathrm{HBV}$. On the other hand, since $\mathrm{CD}^{+} \mathrm{T}$ - cells are required to sustain $\mathrm{CD}^{+}$cytotoxic $\mathrm{T}$-cell responses during chronic viral infection [22-24], the depletion of $\mathrm{CD}^{+}{ }^{+} \mathrm{T}$-cell function may cause a reduction in $\mathrm{HBV}$-specific $\mathrm{CD}^{+}$T-cell responses. 
Indeed, Lascar et al. [25]. reported a reduction in human leukocyte antigen (HLA)-A2-restricted HBV-specific (core 18-27) $\mathrm{CD}^{+}$T-cell response in previously infected HBV subjects who were HIV-positive compared with previously infected HBV subjects who were HIV-negative. Therefore, it is thought that the decrease in both $\mathrm{HBV}$-specific $\mathrm{CD} 4^{+}$ and $\mathrm{CD} 8^{+} \mathrm{T}$-cell responses may account for the weak HBV-specific T-cell responses in individuals with HIV who were previously infected with HBV. Furthermore, the shortage of HBV antigen may be another factor leading to the lower HBV-specific T cell responses in individuals with HIV who had been previously infected with HBV. The reduction in HBV-specific T-cell responses could account for the relatively high prevalence of occult Hepatitis B in HIVinfected patients, especially after withdrawal of HAART [26]. Although the level of plasma HBV DNA was undetectable in the current study in individuals with HIV that had been previously infected with HBV, continuous visits would be required to monitor clinical progression.

There were limitations in the present study. First, we did not know whether co-infected, chronic HBV patients in the cross-sectional study acquired HBV infection prior to HIV infection. However, based on previous epidemiological studies of HBV infection in China, it is highly likely that most of the individuals in cross-sectional study acquired HBV at birth or in early childhood. Patients with HIV in this study were infected as an adult via the route of homosexual contact. Thus, it is reasonable to assume that the individuals in the cross-sectional study were infected with HIV subsequent to HBV. Secondly, we were not able to collect accurate data regarding the time of HBV acquisition in cross-sectional study and could not take into account potential differences in the duration of HBV infection among the mono-and co-infected patients.

Overall, the HBV-specific T-cell responses in co-infected, chronic $\mathrm{HBV}$ patients decreased with disease progression and were positively correlated with HBV viral load. The HBV-specific T-cell responses significantly lower in individuals with HIV who had been previously infected with HBV compared with individuals not co-infected with HIV. Although almost all co-infected, chronic HBV patients had normal liver function in this study, longer follow-up studies of subjects with HIV/HBV co-infections are required to determine the kinetic changes in HBV-specific immune responses and to monitor the disease progression in order to come up with effective approaches to manage those with HIV/HBV co-infections.

\section{Methods}

\section{Subjects}

In the current study, 39 patients infected with HIV-1 were recruited from Beijing Youan Hospital, Capital Medical University, China, to participate in a cross-sectional study. A total of 25 patients had chronic HBV and 14 had been previously infected with HBV. Patients had no history of treatments for either HIV or HBV. The control group was comprised of 32 individuals that were not infected with HIV-1; 16 subjects had chronic HBV and 16 subjects had been previously infected with HBV. All subjects were older than 18 years of age and were negative for hepatitis $\mathrm{C}$ virus antibody. In the chronic HBV patients, HBsAg was positive for $>6$ months prior to analysis. Exclusion criteria included hepatocellular carcinoma, autoimmune liver disease, and liver cirrhosis. Patients that had previous $\mathrm{HBV}$ infection were negative for $\mathrm{HBsAg}$, positive for $\mathrm{HBsAb}$, either positive or negative for $\mathrm{HBeAb}$, and positive for $\mathrm{HBcAb}$.

A total of 11 individuals with acute HIV-1 and chronic HBV infection, who had been HBsAg positive for $>5$ years, were enrolled in a longitudinal study. Follow-up was done in these patients at 3,12, and 24 months after the onset of acute HIV infection. Signed consent was obtained from all subjects with the approval of the institutional ethics committee and the study was in compliance with the Declaration of Helsinki.

\section{Human interferon (IFN)- $\gamma$ ELISPOT assay}

Peripheral whole blood was obtained from all subjects and peripheral blood mononuclear cells (PBMCs) were isolated by density gradient centrifugation with Ficoll Lymphoprep (Axis -Shield PoC AS, Oslo, Norway). Isolated PBMCs were kept in liquid nitrogen. After thawing, PBMCs were incubated at $37^{\circ} \mathrm{C}$ in $5 \% \mathrm{CO}_{2}$ overnight. PBMCs $\left(2.0 \times 10^{5}\right)$ were pulsed with $4 \mu \mathrm{g} / \mathrm{mL}$ recombinant Hepatitis B surface protein and recombinant Hepatitis B core protein (ARP, American Research Products, Inc. ${ }^{\mathrm{m}}$, USA), respectively, and were tested using a standard Human IFN- $\gamma$ ELISPOT assay, in duplicate wells, as described previously [27]. PBMCs $\left(2.0 \times 10^{5}\right)$, from subjects with HIV infection, were pulsed with $1 \mu \mathrm{g} / \mathrm{mL}$ gag peptide pool (comprised of 61 peptides covering the whole gag protein). In brief, assays were carried out in 96-well MultiScreen filter plates (Millipore) coated with $15 \mu \mathrm{g} / \mathrm{mL}$ anti-IFN- $\gamma$ mAb 1-DIK (Mabtech AB, Nacka, Sweden). Three $\mu \mathrm{g} / \mathrm{mL}$ phytohemagglutinin (PHA) (final concentration) was used as a positive control and the negative control wells were stimulated with RPMI 1640 containing $10 \%$ FCS. Plates were incubated at $37^{\circ} \mathrm{C}$ in $5 \% \mathrm{CO}_{2}$ for $16 \mathrm{~h}$. Spot enumeration was performed with an ELISPOT reader system (Antai Yongxin Medical Technology, Beijing, China). To quantify antigenspecific responses, mean spots of the control wells were subtracted from the positive wells, and results were expressed as spot-forming cells (SFC) per $10^{6}$ PBMCs. Responses were considered positive if results were at least twice the mean of the duplicate negative control wells and $>30 \mathrm{SFCs} / 10^{6}$ PBMCs. 


\section{$\mathrm{CD}^{+}$and $\mathrm{CD} 8^{+} \mathrm{T}$-cell ELISPOT assay}

$\mathrm{CD}^{+}$or $\mathrm{CD}^{+} \mathrm{T}$ cells were isolated from PBMCs using the Dynabeads CD4 kit or Dynabeads CD8 kit (Invitrogen Dynal As, Oslo, Norway), according to the manufacturer's instructions. $2.0 \times 10^{5} \mathrm{CD}^{+}$or $\mathrm{CD}^{+}$T-cells were pulsed with $4 \mu \mathrm{g} / \mathrm{mL}$ recombinant Hepatitis $\mathrm{B}$ surface protein, recombinant Hepatitis B core protein (ARP, American Research Products, Inc. ${ }^{\mathrm{T}}$, USA), or with $1 \mu \mathrm{g} / \mathrm{mL}$ of gag peptide pool, and were tested using the standard human IFN- $\gamma$ ELISPOT assay in duplicate wells as above described.

\section{Cytokine responses in cultured supernatants}

Samples of PBMC supernatants, from chronic HBV patients co-infected with HIV, were stimulated with $4 \mathrm{ug}$ / $\mathrm{mL}$ recombinant $\mathrm{C}$ protein. Cultured supernatants were harvested after $2.0 \times 10^{5}$ PBMCs were stimulated, overnight. The negative control well was not stimulated with recombinant C protein but with RPMI 1640 containing $10 \%$ FCS. Levels of cytokines in the cultured supernatants, including IL-2, IL-4, IL-6, IL-8, IL-10, GM-CSF, TNF- $\alpha$, and IFN- $\gamma$, were detected using the Bio-Plex Pro $^{\mathrm{Tm}}$ Human Cytokine Grp I Panel 8-plex kit from Bio$\operatorname{Rad}^{\oplus}$ (magnetic beads, Luminex ${ }^{\oplus}$ USA). The outcome was determined using the index of stimulation (IS) to display the cytokine level of stimulated well. The index of stimulation was taken as the cytokine level of the stimulated well minus the cytokine level of un-stimulated well divided by the cytokine level of un-stimulated well.

\section{HBV DNA and HIV-1 RNA quantification}

HBV DNA was quantified using a domestic HBV DNA assay kit (KeHua Biological Technological Corporation, Beijing, China), according to the manufacturer's instructions (lower limit of detection, 500 copies/mL). HIV RNA was quantified using the Roche RT-PCR assay according to the manufacturer's instructions (Easy Q; Roche; lower limit of detection, $40 \mathrm{IU} / \mathrm{mL}$ ).

\section{Graphing and statistical analysis}

Graphpad Prism 5 software was used to graph and analyze the data and $\mathrm{P}<0.05$ was regarded as statistically significant. Proportion of subjects by gender was determined using Fisher's exact test. Comparison of age, HBV DNA, $\mathrm{CD}^{+}{ }^{+} \mathrm{T}$-cell count, and the magnitude and frequency of specific T-cell responses between the two groups was determined using the Student's t test for parameter variables or the Mann-Whitney U test for non-parameter variables. The correlation between $\mathrm{HBV}$-specific $\mathrm{T}$-cell responses and HBV DNA or $\mathrm{CD}^{+}$T-cell count was determined using Spearman's correlation analysis.

\section{Competing interests}

The authors declare that they have no competing interests.

\section{Authors' contributions}

ZX designed the study, carried out all experiments, performed the statistical analysis and drafted the manuscript. XHQ participated in screening and observing the clinical cases and helped to draft the manuscript. FX carried out part of experiments and screened the clinical cases. ZHP carried out part of experiments. WY carried out part of experiments. YHP conceived of the study, and participated in its design and coordination and helped to draft the manuscript. All authors read and approved the final manuscript.

\section{Funding sources}

This study was founded by Major Project of Beijing Municipal Science and Technology Committee (D09050703590904; D09050703590901), and the National 12th Five-Year Major Projects of China (2012ZX10001-008), and Youan Liver disease and AIDS Foundation, China Primary Health Care Foundation(BJYAH-2011-024).

\section{Author details}

${ }^{1}$ Infection and Immunity Research center of Beijing Youan Hospital, Capital Medical University, Beijing, China100069. '2Liver Failure Treatment \& Research center, 302 Military Hospital, Beijing 100039, China.

Received: 8 April 2013 Accepted: 5 July 2013

Published: 12 July 2013

\section{References}

1. Thio CL, Seaberg EC, Skolasky R Jr, Phair J, Visscher B, Muñoz A, Thomas DL, Multicenter AIDS Cohort Study: HIV-1, hepatitis B virus, and risk of liverrelated mortality in the Multicenter Cohort Study (MACS). Lancet 2002, 360:1921-1926.

2. Piroth L, Sène D, Pol S, Goderel I, Lacombe K, Martha B, Rey D, Loustau-Ratti V, Bergmann JF, Pialoux G, Gervais A, Lascoux-Combe C, Carrat F, Cacoub P: Eidemiology, diagnosis and treatment of chronic hepatitis B in HIVinfected patients (EPIB 2005 STUDY). AIDS 2007, 21:1323-1331.

3. Colin JF, Cazals-Hatem D, Loriot MA, Martinot-Peignoux M, Pham BN, Auperin A, Degott C, Benhamou JP, Erlinger S, Valla D, Marcellin P: Influence of human immunodeficiency virus infection on chronic hepatitis B in homosexual men. Hepatology 1999, 29:1306-1310.

4. Goldin RD, Fish DE, Hay A, Waters JA, McGarvey MJ, Main J, Thomas HC: Histological and immunohistochemical study of hepatitis B virus in human immunodeficiency virus infection. J Clin Pathol 1990, 43:203-205.

5. Ockenga J, Tillmann HL, Trautwein C, Stoll M, Manns MP, Schmidt RE: Hepatitis B and C in HIV-infected patients. Prevalence and prognostic value. J Hepatol 1997, 27:18-24.

6. Puoti M, Torti C, Bruno R, Filice G, Carosi G: Natural history of chronic hepatitis B in co-infected patients. J Hepatol 2006, 44(1):S65-70.

7. Hadler SC, Judson FN, O'Malley PM, Altman NL, Penley K, Buchbinder S, Schable CA, Coleman PJ, Ostrow DN, Francis DP: Outcome of hepatitis B virus infection in homosexual men and its relation to prior human immunodeficiency virus infection. J Infect Dis 1991, 163:454-459.

8. Milich DR, Chen MK, Hughes JL, Jones JE: The secreted hepatitis B precore antigen can modulate the immune response to the nucleocapsid: a mechanism for persistence. J Immunol 1998, 160:2013-2021.

9. Boni C, Bertoletti A, Penna A, Cavalli A, Pilli M, Urbani S, Scognamiglio P, Boehme R, Panebianco R, Fiaccadori F, Ferrari C: Lamivudine treatment can restore T cell responsiveness in chronic hepatitis B. J Clin Inves. 1998, 102:968-975.

10. Ferrari C, Penna A, Bertoletti A, Valli A, Antoni AD, Giuberti T, Cavalli A, Petit MA, Fiaccadori F: Cellular immune response to hepatitis $B$ virus-encoded antigens in acute and chronic hepatitis B virus infection. J Immunol 1990, 145:3442-3449.

11. Liang M, Ma S, Hu X, Zhou B, Zhang J, Chen J, Wang Z, Sun J, Zhu X, Abbott W, Hou J: Cellular immune responses in patients with hepatitis B surface antigen seroclearance induced by antiviral therapy. Virol J 2011, 8:69-76.

12. Lewin SR, Ribeiro RM, Walters T, Lau GK, Bowden S, Locarnini S, Perelson AS: Analysis of hepatitis B viral load decline under potent therapy: complex decay profiles observed. Hepatology 2001, 34:1012-1020.

13. Fried MW, Piratvisuth T, Lau GK, Marcellin P, Chow WC, Cooksley G, Luo KX, Paik SW, Liaw YF, Button P, Popescu M: HBeAg and hepatitis B virus DNA as outcome predictors during therapy with peginterferon alfa-2a for HBeAg-positive chronic hepatitis B. Hepatology 2008, 47:428-434. 
14. Malacarne F, Webster GJ, Reignat S, Gotto J, Behboudi S, Burroughs AK, Dusheiko GM, Williams R, Bertoletti A: Tracking the source of the hepatitis B virus-specific CD8 T cells during lamivudine treatment. J Infect Dis 2003, 187:679-682.

15. Chang JJ, Sirivichayakul S, Avihingsanon A, Thompson AJ, Revill P, Iser D, Slavin J, Buranapraditkun S, Marks P, Matthews G, Cooper DA, Kent SJ, Cameron PU, Sasadeusz J, Desmond P, Locarnini S, Dore GJ, Ruxrungtham K, Lewin SR: Impaired Quality of the Hepatitis B Virus (HBV)-Specific TCell Response in Human Immunodeficiency Virus Type 1-HBV Coinfection. J Virol 2009, 83:7649-7658.

16. Janetzki S, Cox JH, Oden N, Ferrari G: Standardization and Validation Issues of the ELISPOT Assay. In Handbook of ELISPOT: methods and protocols. Edited by Kalyuzhny AE. Totowa, New Jersey: Humana press; 2005:63-64 [Walker JM (Series editor):Methods in Molecular Biology, vol 302.].

17. Currier JR, DeSouza M, Chanbancherd P, Bernstein W, Birx DL, Cox JH: Comprehensive screening for human immunodeficiency virus type 1 subtype specific CD8 cytotoxic T lymphocytes and definition of degenerate epitopes restricted by HLA-A0207 and $-C(w) 0304$ alleles. J Virol 2002, 76:4971-4986.

18. Rosenberg ES, LaRosa L, Flynn T, Robbins G, Walker BD: Characterization of HIV-1 specific T helper cells in acute and chronic infection. Immunol Let 1999, 66:89-93.

19. McMahon BJ: The natural history of chronic hepatitis B virus infection. Hepatology 2009, 49(5):45-55.

20. Chu C, Liaw Y: Chronic hepatitis B virus infection acquired in childhood: special emphasis on prognostic and therapeutic implication of delayed HBeAg seroconversion. J Viral Hepatitis 2007, 14:147-152.

21. Chang JJ, Wightman F, Bartholomeusz A, Ayres A, Kent SJ, Sasadeusz J, Lewin SR: Reduced Hepatitis B virus (HBV)-specific CD4+ T-Cell Responses in Human Immunodeficiency Virus Type 1-HBV Co-infected Individuals Receiving HBV-Active Antiretroviral Therapy. J Virol 2005, 79:3038-3051.

22. Matloubian M, Concepcion RJ, Ahmed R: CD4 T cells are required to sustain CD8 cytotoxic T-cell responses during chronic viral infection. J Virol 1994, 68:8056-8063.

23. Janssen EM, Lemmens EE, Wolfe T, Christen U, von Herrath MG, Schoenberger SP: CD4+ T cells are required for secondary expansion and memory in CD8 + T lymphocytes. Nature 2003, 421:852-856.

24. Belz GT, Wodarz D, Diaz G, Nowak MA, Doherty PC: Compromised influenza virus-specific CD8 + T cell memory in CD4+ T cell deficient mice. J Virol 2002, 76:12388-12393.

25. Lascar RM, Lopes AR, Gilson RJ, Dunn C, Johnstone R, Copas A, Reignat S, Webster G, Bertoletti A, Maini MK: Effect of HIV Infection and Antiretroviral Therapy on Hepatitis B Virus (HBV)-Specific T-cell responses in Patients Who Have Resolved HBV Infection. J Infect Dis 2005, 191:1169-1179.

26. Cohen Stuart JW, Velema M, Schuurman R, Boucher CA, Hoepelman Al: Occult Hepatitis B in persons infected with HIV is associated with low CD4 counts and resolves during antiretroviral therapy. J Med Virol 2009, 81:441-445

27. Zhang $Y$, Peng $Y$, Yan $H$, Xu K, Saito $M, W u H$, Chen $X$, Ranasinghe $S$, Kuse N, Powell T, Zhao Y, Li W, Zhang X, Feng X, Li N, Leligdowicz A, Xu X, John M, Takiguchi M, McMichael A, Rowland-Jones S, Dong T: Multilayered Defense in HLA-B51-Associated HIV Viral Control. J Immunol 2011, 187:684-691.

doi:10.1186/1743-422X-10-232

Cite this article as: Zhang et al:: Hepatitis B virus (HBV)-specific T-cell responses to recombinant HBV core protein in patients with normal liver function and co-infected with chronic HBV and human immunodeficiency virus 1 (HIV-1). Virology Journal 2013 10:232.

\section{Submit your next manuscript to BioMed Central and take full advantage of:}

- Convenient online submission

- Thorough peer review

- No space constraints or color figure charges

- Immediate publication on acceptance

- Inclusion in PubMed, CAS, Scopus and Google Scholar

- Research which is freely available for redistribution

Submit your manuscript at www.biomedcentral.com/submit 